\title{
Regeneración ósea guiada utilizando membrana de óxido de aluminio en combinación con implantes oseointegrados
}

\section{Guided bone regeneration using aluminum oxide membrane in combination with osseointegrated implants}

\author{
M. Isa Majlufi, J. Harán Vega², G. Moreno Zárate
}

Resumen: La reabsorción ósea de los maxilares ha sido una de las mayores complicaciones al momento de rehabilitar a pacientes con implantes oseointegrados. El siguiente estudio evaluó la efectividad de la membrana de óxido de aluminio (alúmina), en la regeneración ósea de rebordes colapsados y alvéolos en los que se colocaron implantes. De un total de cinco pacientes seleccionados, se estudiaron siete sitios de los cuales tres correspondieron a un solo paciente. En cada sitio (alvéolo o reborde colapsado) se colocó un implante de titanio del sistema HIS y una membrana no biodegradable de óxido de aluminio (Allumina ${ }^{\circledR}$ ), la cual fue retirada a las 14 semanas. Todos los pacientes fueron sometidos al mismo procedimiento quirúrgico. La ganancia promedio en $\mathrm{mm}$ obtenidos en orden decreciente fue la siguiente: ANM: 1.7mm, ANME: 1.6mm, AND: 1.1mm, AV: 1.0mm, AP: $0.5 \mathrm{~mm}$. Los resultados radiográficos ratificaron los resultados clínicos en cuanto a neoformación ósea, observándose además una favorable densidad ósea periimplantaria. El análisis estadístico (basado en los resultados clínicos) t-student fue significativo para todos los parámetros evaluados con excepción de AP.

Palabras clave: Membrana; Alúmina; Regeneración ósea; Implante.

Recibido: 16.01 .06

Aceptado: 01.06 .07

\begin{abstract}
Alveolar bone loss has been a very important cause of complications in osseointegrated implant rehabilitation of edentulous patients. This paper evaluates the effectiveness of aluminum oxide membrane (Allumina) in the collapsed alveolar ridge where implants were used. Seven sites were studied in 5 patients. In each of these sites a HIS implant plus a non-biodegradable oxide aluminum membrane (Allumina $\left.{ }^{\circledR}\right)$, was placed for 14 weeks. All patients were treated with the same surgical protocol. The average gain (in $\mathrm{mm}$ ) obtained in decreasing order was as follows: ANM: $1.7 \mathrm{~mm}$, ANME: $1.6 \mathrm{~mm}$, AND: $1.1 \mathrm{~mm}, A V: 1.0 \mathrm{~mm}, A P: 0.5 \mathrm{~mm}$. The clinical results were radiographically verified and these showed bone neoformation, in addition to favorable peri-implant bone density. The t-Student statistical analysis based on the clinical results was significant for all the parameters evaluated with the exception of AP.
\end{abstract}

Key words: Membrane; Allumina; Bony regeneration; Implant.

\footnotetext{
1 Profesor Asistente, Departamento de Cirugía y Traumatología Maxilo-Facial.

2 Cirujano Dentista.

3 Profesor del Departamento de Radiología.

Universidad de Chile, Santiago de Chile, Chile
}

\section{Correspondencia:}

Dr. Mario Isa Majluf

Apdoquindo 4100 dpto. 601 Las Condes

Santiagode de Chile, Chile

Email: Isamohor@ctcinternet.cl 


\section{Introducción}

La reabsorción ósea alveolar es un proceso fisiológico que se puede producir como consecuencia a una extracción dentaria. ${ }^{11}$ El volumen suficiente de hueso es considerado como el prerequisito más importante para el pronóstico a largo plazo de los implantes. ${ }^{9}$ Numerosos autores han realizado estudios probando gran cantidad de materiales de injertos y membranas con la finalidad de mejorar las condiciones del reborde y también en los casos de dehiscencias al momento de instalación de implante. Estos biomateriales han sido utilizados en forma independiente y en conjunto logrando diferentes grados de éxito. ${ }^{18} \mathrm{La}$ mayoría de las membranas utilizadas en regeneración tisular guiada, requieren de un material de relleno para evitar su colapso.

En el año 1999 Isa y cols. utilizaron una membrana de óxido de aluminio para la preservación del reborde alveolar post exodoncia de terceros molares inferiores, sin materiales de injerto, obteniendo excelentes resultados. ${ }^{25}$ Petersen y colaboradores, utilizaron estas mismas membranas de alúmina en tratamiento de furcas tipo II en humanos con excelentes resultados. ${ }^{28}$

El presente estudio reporta nuestros resultados utilizando membrana de óxido de aluminio para mejorar la condición del reborde alveolar donde se colocaron implantes, sin emplear materiales de injerto.

\section{Material y método}

\section{Pacientes. Criterios de inclusión}

- Buen estado de salud general y oral

- Ausencia absoluta de cualquier contraindicación para ser rehabilitados con implantes oseointegrados

- Buena disposición y capacidad para entender y seguir las indicaciones estrictamente.

- Adultos jóvenes entre 20 y 45 años.

- Pacientes con sitios edéntulos colapsados, con suficiente remanente óseo que permita la estabilidad inicial del dispositivo implantado, o bien, con piezas dentarias con indicación de extracción y pérdida ósea, sin patología ni procesos infecciosos

Cinco pacientes constituyen el grupo seleccionado, con 7 "sitios de estudio", en los que se insertó un implante con su respectiva membrana.

Sitio 1 - Alvéolo pieza 19; Sitio 2- Alvéolo pieza 12; Sitio 3- Alvéolo pieza 8; Sitio 4-Reborde alveolar en zona de pieza 7; Sitio 5 Reborde alveolar en zona de pieza 8; Sitio 6 - Reborde alveolar en zona de pieza 9; Sitio 7 - Reborde alveolar en zona de pieza 10.

En los sitios 1-2 y 3 se alojaron implantes inmediatos. Los sitios 5-6 y 7 correspondieron a un mismo paciente.

Para este estudio utilizamos como barrera física la membrana de óxido de aluminio, 25 espesor medio $(0,06 \mathrm{~mm})$. Esta se mantuvo en su sitio durante 14 semanas.

\section{Estudio clínico}

En el caso de los alvéolos las medidas tomadas fueron las siguientes:

\section{Introduction}

Alveolar bone resorption is a physiological process that can arise as a result of dental extraction. ${ }^{11}$ Sufficient bone volume is considered the most important prerequisite for the long-term prognosis of implants. ${ }^{9}$ Numerous authors have carried out studies with a large quantity of graft and membrane material with the aim of improving the condition of the ridge, and also in cases of dehiscence when placing the implant. These biomaterials have been used independently and together, and different degrees of success have been achieved..$^{18}$ Most of the membranes used in guided bone regeneration require a filling material for avoiding collapse.

In 1999 Isa and col. used aluminum oxide membrane for preserving the alveolar ridge after the extraction of lower third molars without graft material, and they obtained excellent results. ${ }^{25}$ Petersen and cols. used these same aluminum membranes for treating type II fork branches in humans with excellent results. ${ }^{28}$ This study provides our results with aluminum oxide membranes for improving the condition of the alveolar ridge in which implants were installed, without using graft material.

\section{Material and method}

Patients. Inclusion criteria

- Good general and oral health.

- Total absence of any contraindication for rehabilitation with osseointegrated implants.

- Good disposition and capacity for understanding and following instructions strictly.

- Young adults between the ages of 20 and 45 .

- Patients with collapsed edentulous areas, with sufficient remaining bone to permit the initial stability of the implanted structure, or teeth with signs of extraction and bone loss, without any pathologies or infectious processes.

Five patients made up the selected group with 7 "study sites" into which an implant was inserted with its respective membrane.

Site 1- Socket tooth 19; Site 2- Socket tooth 12; Site 3Socket tooth 8; Site 4-Alveolar ridge in site of tooth 7; Site 5 - Alveolar ridge in site of tooth 8; Site 6 - Alveolar ridge in site of tooth 9; Site 7 - Alveolar ridge in site of tooth 10.

In Sites 1-2 and 3, implants were immediately inserted. Sites 5-6 and 7 related to the same patient.

For this study an aluminum oxide membrane was used as a physical barrier, ${ }^{25}$ mean thickness $(0.06 \mathrm{~mm})$. This was kept in place for 14 weeks.

\section{Clinical study}

With regard to the sockets, the following measurements were taken: 
Altura de la tabla vestibular en su porción media, Altura de la tabla palatina o lingual en su porción media, Ancho del alvéolo en su porción media, Ancho del alvéolo en su porción mesial y Ancho del alvéolo en su porción distal.

En rebordes colapsados donde las tablas no se distinguían, las medidas se tomaron una vez fabricado el lecho óseo que alojaría el implante y fueron las siguientes:

Altura del borde vestibular del lecho óseo en su porción media, Altura del borde palatino o lingual del lecho óseo en su porción media, Ancho del reborde en su porción media, Ancho del reborde en su porción mesial y Ancho del reborde en su porción distal.

Para el registro de las alturas se utilizaron dos reglas metálicas estériles, una de ellas se posicionó desde los puntos señalados anteriormente hasta una línea imaginaria que correspondía a la proyección del plano oclusal, para ello se utilizó otra regla estéril en sentido horizontal como referencia. Esta regla se apoyó en los bordes incisales o caras oclusales de las piezas vecinas al vano, de este modo, la altura se registró con la regla en sentido vertical perpendicular a la de referencia.

Las dimensiones de espesor fueron registradas con un calibrador de metales.

Estas mediciones fueron tomadas al momento de la primera cirugía previo a la instalación de los implantes y membranas, como también, al momento de la segunda intervención al ser retirada la membrana a las 14 semanas (Fig. 1).

Se utilizó radiografías panorámicas y retro alveolares antes de la primera cirugía, con fecha no superior a un mes antes de la fecha de la intervención quirúrgica y una vez retiradas las membranas a las 14 semanas para medir densidad y la altura ósea.

\section{Acto quirúrgico}

En el pre-operatorio se prescribió Amoxicilina de 750 mg, 1 comprimido 6 horas antes de la intervención y Betametasona 0,6 mg, 5 comprimidos media hora antes de la cirugía. Técnica anestésica infiltrativa, Mepivacaina al 2\%. Se efectuaron las exodoncias de las piezas en el caso de los implantes inmediatos. Posteriormente se prosiguió indistintamente para los dos casos en estudio de la siguiente manera:

Colgajo muco periostio crevicular con dos descargas verticales que parten de la unión mucogingival hasta la base de las papilas que limitan el vano (mesial y distal). Fabricación del lecho óseo en el reborde colapsado o alvéolo según el caso, -Inserción del
Height of the vestibular plate at mean portion. Height of the palatal or lingual plate at mean portion, width of socket at mean portion, width of socket at mesial portion and width of socket at distal portion.

In collapsed ridges where the plates could not be distinguished, the measurements were taken once the bony bed that was to house the implant had been made, and these were the following:

Height of the vestibular ridge of the bony bed at mean portion, height of the palatal or lingual ridge of the bony bed at mean portion, width of the ridge at mean portion, width of the ridge at mesial portion and width of the ridge at distal portion.

For registering height, two sterile metallic rulers were used. One of them was positioned at the points previously indicated up to an imaginary line that corresponded with the projection of the occlusal plane. For this, another sterile ruler was used in a horizontal direction as a reference. This ruler was put against the incisal borders or occlusal faces of the teeth by the gap. In this way the height was registered in a vertical sense, perpendicular to the reference point.

The thickness dimensions were registered with a metal calibrator.

These measurements were taken at the time of the first surgery before the placement of the implants and membranes, as well as at the second intervention when the membrane was removed at 14 weeks (Fig. 1).

Panoramic and retroalveolar radiographies were used before the first surgical intervention, with data of not more than a month before the date of the surgical intervention, and once the membranes had been removed at 14 weeks in order to measure density and bone height.

\section{Surgical act}

In the pre-operative period, Amoxicillin of $750 \mathrm{mg}$ was prescribed, 1 tablet 6 hours before the intervention, and Betamethasone $0.6 \mathrm{mg}, 5$ tablets half an hour before the surgery. Infiltrative anesthetic technique, Mepivacaine at 


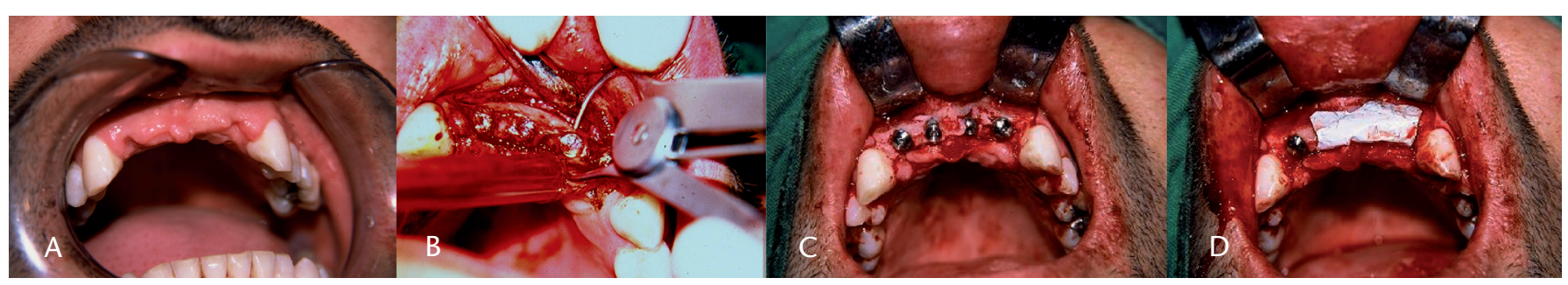

Figura 1. Mediación de las dimensiones del reborde alveolar óseo.

Figure 1. Measurement of the dimensions of the bony alveolar ridge.

implante en el lecho quirúrgico con técnica convencional, - Sección parcial del periostio de la base del colgajo para dar mayor elasticidad a éste, -Manipulación y recorte e instalación de la membrana asegurando el correcto sellado de ella sobre el hueso. Sutura, dejando la membrana totalmente cubierta.

Todos los pacientes fueron sometidos a una medicación postoperatoria con Amoxicilina $750 \mathrm{mg}$ cada 8 horas durante 7 días, analgésicos, de elección Nimesulida (Aldoron $\left.{ }^{\circledR}\right) 100$ mg 1 tableta cada 12 horas según dolor, Gluconato de clorhexidina al 0,12\% colutorios, 2 veces al día durante 14 días. En casos de exposición de la membrana se debió continuar con el colutorio por mayor tiempo.

Se indicaron revulsivos para controlar el edema, se indicó además el no hablar ni gesticular mucho. Al momento de comunicarse, los pacientes debían hacerlo por escrito por lo menos durante la primera semana. Finalmente los controles se realizaron al segundo día de la cirugía, luego semanalmente el primer mes y cada 15 días los meses restantes. Los pacientes con membrana expuesta se controlaron semanalmente (Fig. 2).

\section{Resultados}

Después de la primera cirugía, la inflamación que presentaron los pacientes fue leve y no se extendió más allá de 3 días. Sin grandes complicaciones y completada la terapia antibiótica los pacientes continuaron con el uso de Clorhexidina (Perio-Aid ${ }^{\circledR}$ ) hasta completar los 15 días indicados. En 3 pacientes (Sitios $N^{\circ} 1, N^{\circ} 2$, y $N^{\circ} 4$ ) hubo exposición prematura. Los Sitios $\mathrm{N}^{\circ} 1$ y $\mathrm{N}^{\circ} 4$ fueron los que mayor exposición presentaron, este hecho no mostró signos ni síntomas de infección asociados por lo que se indicó en estos pacientes el uso adicional del antiséptico y muy buen control de placa durante el tiempo restante de estudio. Debido a esto, no hubo que retirar la membrana antes del tiempo estipulado.

A las 14 semanas fueron retiradas las membranas. Aquellas que habían presentado exposición prematura fueron fácilmente retiradas sin necesidad de grandes colgajos. Bajo las membranas más expuestas y en relación a su cara interna (sobre los defectos) se observó un tejido de granulación pero solo en superficie, ya que al realizar las segundas mediciones clínicas pudimos constatar la presencia de tejido de neoformación ósea bajo éste. El Sitio Nํ2 a pesar de su leve exposición no presentó estas características ya que al retirar la membrana se pudo observar un tejido con aspecto de periós-
2\%. Tooth extractions were carried out in the immediate implant cases. Then, the two cases in the study were dealt with indistinctly in the following fashion:

Mucoperiosteal crevicular flap with two vertical incisions, from the mucogingival union to the base of the papillae at the edge of the gap (mesially and distally). Making of the bony bed in the collapsed ridge or socket according to the case, insertion of the implant into the surgical bed following the conventional technique. Partial sectioning of the periosteum from the base of the flap in order to give more elasticity. Handling, shaping and installing the membrane, ensuring the bone is completely sealed with the membrane. Suturing, leaving the membrane totally covered.

All the patients were given postoperative medication with Amoxicillin $750 \mathrm{mg}$ every 8 hours for 7 days, analgesics, of choice Nimesulide (Aldoron ${ }^{\circledR}$ ) $100 \mathrm{mg} 1$ tablet every 12 hours depending on the pain, chlorhexidine gluconate rinse at $0.12 \%$ twice a day for 14 days. In membrane exposure cases the rinse was continued for longer.

Revulsive treatment was given for controlling the edema and instructions were given to the patient not to speak or gesticulate much. When wishing to communicate they had to do this in writing for at least the first week. Finally, the evaluations were carried out the second day after the surgery, then weekly during the first month, and every two weeks for the remaining months. The patients with exposed membranes were followed weekly.

\section{Results}

Clinical results. After the first intervention, there was only slight inflammation that did not continue for more than three days. As there were no major complications, the patients continued using Chlorhexidine (Perio-Aid ${ }^{\circledR}$ ) for the 15 days indicated. In 3 patients (Sites $N^{\circ} 1, N^{\circ} 2$, and $N^{\circ} 4$ ) there was premature exposure. Sites $N^{\circ} 1$ and $N^{\circ} 4$ were those with the greatest exposure, and as there were no associated signs or symptoms of infection, the patients were instructed to use additional antiseptic and to maintain good plaque control for the remainder of the study. Due to this, the barrier did not have to be removed before the stipulated time. 
tio y bajo él neoformación ósea. En el resto de los Sitios sin exposición $\left(\mathrm{N}^{\circ} 3, \mathrm{~N}^{\circ} 5, \mathrm{~N}^{\circ}\right.$ 6 y $\mathrm{N}^{\circ} 7$ ), se repitió en mayor o menor grado el mismo patrón con un tejido semejante a perióstio bastante firme y grueso de aspecto transparente en proceso de maduración, al momento de retirar la membrana.

En general, todas las nuevas mediciones clínicas revelaron mayor neoformación de tejido óseo, a excepción del sitio $\mathrm{N}^{\circ} 1$ cuyas alturas vestibular y palatinas disminuyeron levemente; sin embargo, las dimensiones en relación al ancho del reborde aumentaron favorablemente sobre todo en los aspectos mesial y distal.

Las dehiscencias en relación a los implantes fueron notablemente reparadas en la mayoría de los casos, con excepción del Sitio $\mathrm{N}^{\circ} 1$ cuyo defecto vestibular se mantuvo.

Especial mención merece el Sitio $\mathrm{N}^{\circ} 4$ cuyo reborde se encontraba inicialmente muy colapsado y presentó exposición prematura de la membrana. La recuperación de las dimensiones del reborde sobre todo en sus aspectos ancho medio, mesial y distal de este Sitio fueron notables.

El resumen de las mediciones clínicas tomadas antes y después de la instalación de las membranas e implantes, así como los milímetros ganados en el período de estudio, se encuentran resumidos en las tablas 1 y 2 .

Como los resultados clínicos lo reflejan, los promedios en $\mathrm{mm}$ de todos los sitios fueron favorables. Especial mención merecen la recuperación general del reborde en sus aspectos medio y mesial con una media de $1,7 \mathrm{~mm}$ y $1,6 \mathrm{~mm}$ respectivamente (Figs. 3 y 4 ).

Table 2. MM of bone gain at 14 weeks
Tabla 1. Medidas clinicas previas y posteriores

\begin{tabular}{|c|c|c|c|c|c|c|c|c|c|c|}
\hline & \multicolumn{2}{|c|}{$\begin{array}{c}\text { Altura } \\
\text { Vestibular } \\
(\mathrm{mm})\end{array}$} & \multicolumn{2}{|c|}{$\begin{array}{c}\text { Altura } \\
\text { Palatina o } L \\
\text { (mm) }\end{array}$} & \multicolumn{2}{|c|}{$\begin{array}{l}\text { Ancho } \\
\text { Medio } \\
(\mathrm{mm})\end{array}$} & \multicolumn{2}{|c|}{$\begin{array}{l}\text { Ancho } \\
\text { Mesial } \\
(\mathrm{mm})\end{array}$} & \multicolumn{2}{|c|}{$\begin{array}{l}\text { Ancho } \\
\text { Distal } \\
(m m)\end{array}$} \\
\hline & Pre & Post & Pre & Post & Pre & Post & Pre & Post & Pre & Post \\
\hline Sitio 1 & 14,5 & 15 & 10,5 & 11 & 10,1 & 11 & 4,9 & 8 & 5,3 & 8 \\
\hline Sitio 2 & 5,5 & 5 & 9 & 9 & 9,5 & 11 & 9 & 12 & 10,5 & 12 \\
\hline Sitio 3 & 13 & 12 & 10,5 & 10 & 7,1 & 8 & 10 & 11 & 9 & 11 \\
\hline Sitio 4 & 11,5 & 9 & 9 & 8 & 1,5 & 5,6 & 2,5 & 5,5 & 5,5 & 5.5 \\
\hline Sitio 5 & 14,5 & 13 & 10 & 10 & 3,4 & 4,8 & 3 & 4 & 2 & 4 \\
\hline Sitio 6 & 14,5 & 12,5 & 12,5 & 11 & 2,1 & 5,4 & 2 & 2 & 2,5 & 3 \\
\hline Sitio 7 & 13 & 12,5 & 11 & 9,8 & 5,3 & 5,7 & 5,4 & 6 & 5,5 & 6,5 \\
\hline
\end{tabular}

Table 1. Pre- and post clinical measurement

\begin{tabular}{|c|c|c|c|c|c|c|c|c|c|c|}
\hline & \multicolumn{2}{|c|}{$\begin{array}{l}\text { Height } \\
\text { Vestibular } \\
(\mathrm{mm})\end{array}$} & \multicolumn{2}{|c|}{$\begin{array}{l}\text { Height } \\
\text { Palatal or L } \\
(\mathrm{mm})\end{array}$} & \multicolumn{2}{|c|}{$\begin{array}{l}\text { Width } \\
\text { Mean } \\
(\mathrm{mm})\end{array}$} & \multicolumn{2}{|c|}{$\begin{array}{l}\text { Width } \\
\text { Mesial } \\
(\mathrm{mm})\end{array}$} & \multicolumn{2}{|c|}{$\begin{array}{l}\text { Width } \\
\text { Distal } \\
(\mathrm{mm})\end{array}$} \\
\hline & Pre & Post & Pre & Post & Pre & Post & Pre & Post & Pre & Post \\
\hline Site 1 & 14,5 & 15 & 10,5 & 11 & 10,1 & 11 & 4,9 & 8 & 5,3 & 8 \\
\hline Site 2 & 5,5 & 5 & 9 & 9 & 9,5 & 11 & 9 & 12 & 10,5 & 12 \\
\hline Site 3 & 13 & 12 & 10,5 & 10 & 7,1 & 8 & 10 & 11 & 9 & 11 \\
\hline Site 4 & 11,5 & 9 & 9 & 8 & 1,5 & 5,6 & 2,5 & 5,5 & 5,5 & 5.5 \\
\hline Site 5 & 14,5 & 13 & 10 & 10 & 3,4 & 4,8 & 3 & 4 & 2 & 4 \\
\hline Site 6 & 14,5 & 12,5 & 12,5 & 11 & 2,1 & 5,4 & 2 & 2 & 2,5 & 3 \\
\hline Site 7 & 13 & 12,5 & 11 & 9,8 & 5,3 & 5,7 & 5,4 & 6 & 5,5 & 6,5 \\
\hline
\end{tabular}

Tabla 2. MM de hueso ganados a las 14 semanas

$\begin{array}{lccccc}\text { Altura } & \begin{array}{c}\text { Altura } \\ \text { Vestibular } \\ (\mathbf{m m})\end{array} & \begin{array}{c}\text { Ancho } \\ \text { Palina o L } \\ (\mathrm{mm})\end{array} & \begin{array}{c}\text { Medio } \\ (\mathrm{mm})\end{array} & \begin{array}{c}\text { Ancho } \\ \text { Mesial } \\ (\mathrm{mm})\end{array} & \begin{array}{c}\text { Ancho } \\ \text { Distal } \\ (\mathrm{mm})\end{array} \\ \text { Sitio 1 } & -0,5 & -0,5 & 0,9 & 3,1 & 0,7 \\ \text { Sitio 2 } & 0,5 & 0 & 1,5 & 3 & 1,5 \\ \text { Sitio 3 } & 1 & 0.5 & 0,9 & 1 & 2 \\ \text { Sitio 4 } & 2,5 & 1 & 4,1 & 3 & 0 \\ \text { Sitio 5 } & 1,5 & 0 & 1,4 & 1 & 2 \\ \text { Sitio 6 } & 2 & 1,5 & 3,3 & 0 & 0,5 \\ \text { Sitio 7 } & 0,5 & 1,2 & 0,4 & 0,6 & 1 \\ \text { Promedios } & 1 & 0.5 & 1,7 & 1,6 & 1,1\end{array}$

\begin{tabular}{|c|c|c|c|c|c|c|}
\hline & $\begin{array}{l}\text { Height } \\
\text { Vestibular } \\
\text { (mm) }\end{array}$ & $\begin{array}{l}\text { Height } \\
\text { Palatal or L } \\
\quad(\mathrm{mm})\end{array}$ & $\begin{array}{l}\text { Width } \\
\text { Mean } \\
(\mathrm{mm})\end{array}$ & $\begin{array}{c}\text { Width } \\
\text { Mesial } \\
(\mathrm{mm})\end{array}$ & $\begin{array}{l}\text { Width } \\
\text { Distal } \\
(\mathrm{mm})\end{array}$ & $\begin{array}{l}\text { removing the } \\
\text { membrane, as tis- } \\
\text { sue that was more } \\
\text { or less like perios- }\end{array}$ \\
\hline Site 1 & $-0,5$ & $-0,5$ & 0,9 & 3,1 & 0,7 & teum could be \\
\hline Site 2 & 0,5 & 0 & 1,5 & 3 & 1,5 & observed that was \\
\hline Site 3 & 1 & 0.5 & 0,9 & 1 & 2 & $\begin{array}{l}\text { observea that was } \\
\text { firm and thick }\end{array}$ \\
\hline Site 4 & 2,5 & 1 & 4,1 & 3 & 0 & ind thick \\
\hline Site 5 & 1,5 & 0 & 1,4 & 1 & 2 & with a transparent \\
\hline Site 6 & 2 & 1,5 & 3,3 & 0 & 0,5 & appearance, and \\
\hline Site 7 & 0,5 & 1,2 & 0,4 & 0,6 & 1 & which was in the \\
\hline Average & 1 & 0.5 & 1,7 & 1,6 & 1,1 & process of matur- \\
\hline
\end{tabular}

In general, all the new clinical measurements revealed new bone tissue formation, with the exception of Site $\mathrm{N}^{\circ} 1$ 


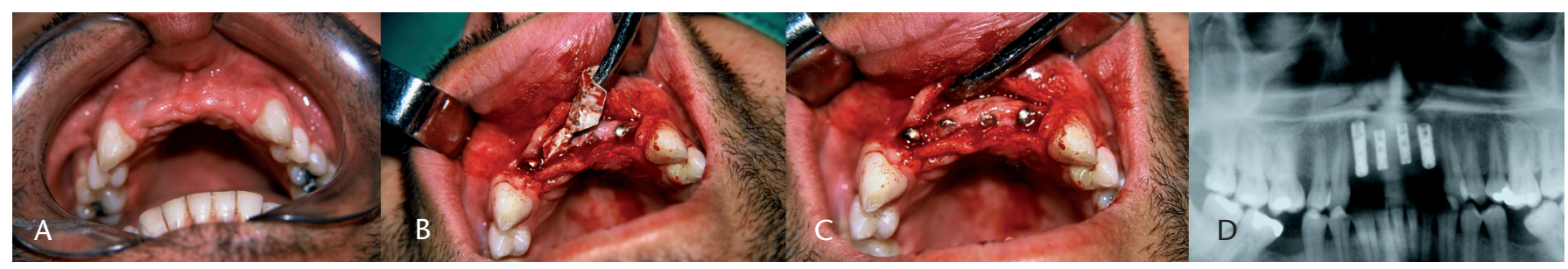

Figura 3. A) Aspecto del reborde a las 14 semanas; B) retirada de la membrana; C) dehiscencias cubiertas por el tejido neoformado; D) control radiográfico.

Figure 3. A) Ridge appearance at 14 weeks; B) membrane removal; C) dehiscences covered by newly formed tissue; D) radiographic evaluation.

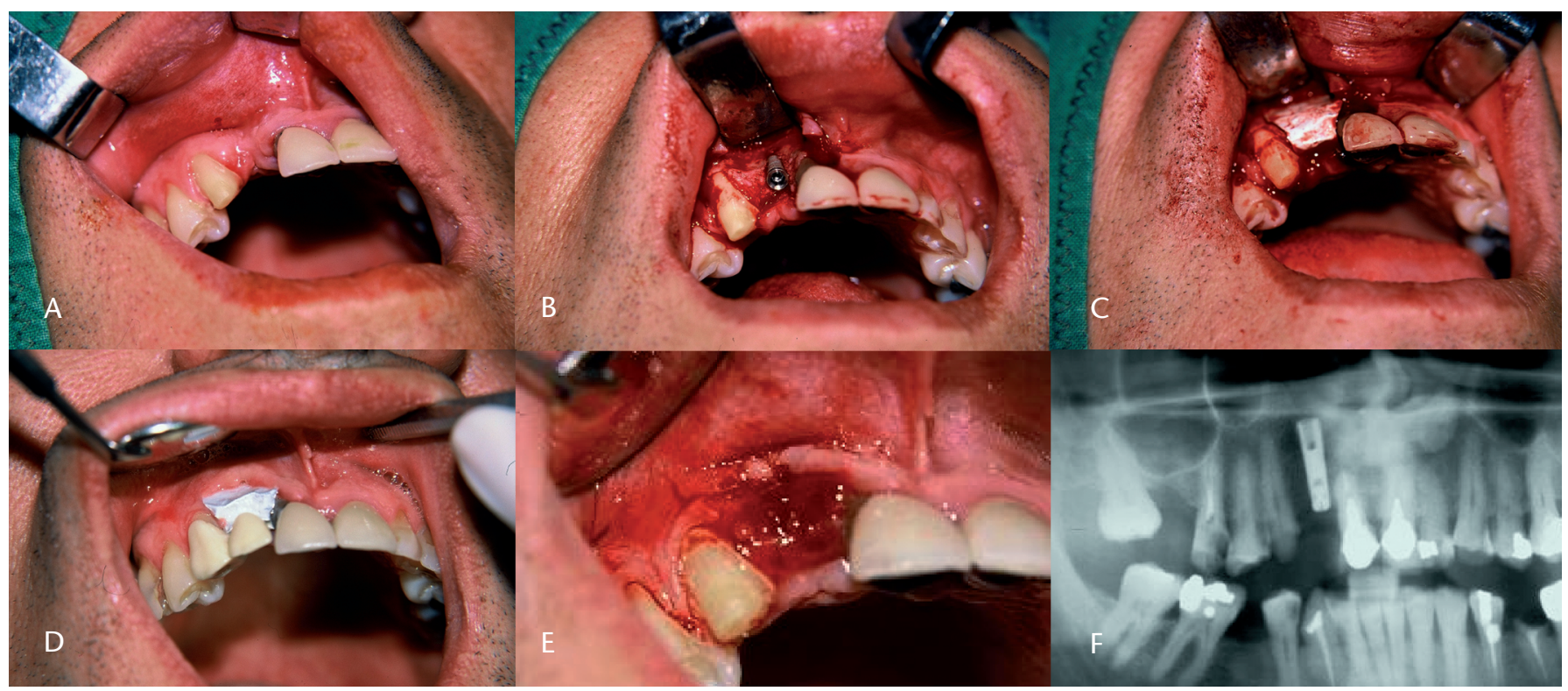

Figura 4. Sitio 4: A) reborde colapsado; B) implante instalado, presencia de extensa dehiscencia; C)membrana instalada; D) exposición de la membrana (14 semanas); E) aspecto del reborde una vez retirada la membrana, se observa tejido de granulación; F) control radiográfico.

Figure 4. Site 4: A) collapsed ridge; B) implant once installed, presence of extensive dehiscence; C) membrane once installed; D) membrane exposure (14 weeks); appearance of ridge after membrane removal, granulation tissue can be observed; F) radiographic evaluation.

\section{Análisis estadístico}

Los resultados clínicos fueron sometidos a un análisis estadístico t-student para muestras pariadas. Se escogió este test ya que permite comparar dos valores, antes y después en una misma unidad de observación.

Los resultados del valor $p$-value para lo distintos sitios están registrados en la tabla 3.

Los resultados del análisis estadístico revelan que los cambios de altura y grosor del reborde antes y después de colocada la membrana son estadísticamente significativos en todos los parámetros evaluados, con excepción del parámetro Altura palatina cuyo valor $p$ final fue mayor de 0,05.

\section{Discusión}

Para nuestro estudio utilizamos la membrana de óxido de aluminio que a, diferencia de otras, permite mantener el espacio bajo that had vestibular and palatal height that was slightly lower. However, the dimensions in relation to the width of the ridge increased favorably, especially mesially and distally.

Dehiscences concerning the implants were noticeably repaired in most cases, with the exception of Site $N^{\circ} 1$, as the vestibular defect remained.

A special mention should be made of Site $N^{\circ} 4$ that initially had a very collapsed ridge and premature membrane exposure. The recovery of the ridge dimensions, especially of the mean, mesial and distal widths in this site was noteworthy.

Tables 1 and 2 give a summary of the clinical measurements taken before and after the placement of membranes and implants, as well as the millimeters gained during the study period.

The clinical results are reflected in the average $\mathrm{mm}$ measurement in all the sites, which were favorable. A special mention should be made of the general recovery of the medial and mesial aspects, with an average of $1.7 \mathrm{~mm}$ and 1.6 
ella sin material para injerto, para reparar principalmente defectos óseos periimplantarios y recuperar o mantener las dimensiones del reborde alveolar.

Nuestro periodo de estudio se limitó a 14 semanas, pasado este plazo se registraron las nuevas medidas de altura y grosor del reborde. La remoción de las membranas en este periodo y no mas allá podría favorecer la maduración del tejido óseo formado ya que la membrana utilizada es impermeable no permitiendo el paso de nutrientes a la zona de reparación y sería el mismo perióstio el encargado de favorecer este proceso una vez retirada la barrera. Los resultados revelaron en promedio una mayor cantidad de tejido óseo en todos los parámetros evaluados. La altura palatina fue el único parámetro evaluado que no tuvo un resultado estadísticamente significativo, a pesar de esto, los valores de las segundas mediciones en este parámetro arrojaron un valor final positivo, es decir, la ganancia de $\mathrm{mm}$ se obtuvo de todas maneras pero en menor grado que las demás.

La diferencia entre los resultados de altura palatina y vestibular no deberían sorprender si consideramos que, en general las dehiscencias se producen en vestibular. Por otro lado, numerosos estudios previos, $^{18}$ han atribuido a las membranas utilizadas en RTG más capacidad de recuperación de los rebordes alveolares en sentido horizontal que en sentido vertical, debido principalmente a la tendencia al colapso que estas sufren, por presión de los tejidos blandos.

La membrana utilizada en este estudio no sufrió ningún signo de colapso y en todos los casos los resultados fueron favorables. Sin embargo, dado el hecho que empleamos la membrana de espesor medio que no es habitualmente la indicada para gran aumento en altura, se logró esta ganancia evitando crear un gran espacio bajo ella, en especial en altura, al ser adaptada sobre los sitios en estudio. Este podría haber sido el motivo por el que las medidas posteriores de altura hayan sido las menos significativas clínicamente.

El sitio $N^{\circ} 1$ correspondiente al alvéolo de la pieza 19, fue el único sitio ubicado en mandíbula y el único que presentó pérdida de altura tanto en vestibular como en palatino. El tipo de irrigación mandibular y el diseño del colgajo (Newman) podrían explicar en parte dichos resultados. El aporte vascular de la mandíbula depende principalmente del suministro por parte de los tejidos blandos, en espe-

$\mathrm{mm}$ respectively

(Figs. 3 and 4).

$\begin{array}{cc}\begin{array}{c}\text { Variación } \\ (\mathrm{mm})\end{array} & \begin{array}{c}\text { P-value } \\ (\mathrm{mm})\end{array} \\ 1,071 & 0,032 \\ 0,529 & 0,105 \\ 1,786 & 0,014 \\ 1,671 & 0,015 \\ 1,100 & 0,009\end{array}$

value

0,032

0,014

0,009

\section{(Figs. 3 and 4$)$.}

\section{Statistical analysis}

The clinical results were subjected to a statistical t-Student analysis for paired samples. This test was chosen because it allows the comparison of two values, before and after, in the same observation unit.

The results of the $p$ value for the different sites are registered in table 3.

The results of the statistical analysis reveal that the changes in height and thickness of the ridge, before and after membrane placement, are statistically significant in all the parameters evaluated, with the exception of the palatal Height parameter that had a final $p$-value that was more than 0.05 .

\section{Discussion}

For our study we used aluminum oxide membrane, which unlike other membranes allows maintaining the space underneath without any graft material, for repairing mainly periimplant bone defects and for recovering and maintaining the dimensions of the alveolar ridge.

Our study period was limited to 14 weeks. After this period the new height and thickness of the ridges was recorded. Membrane removal in this period and not afterwards, could encourage the bone tissue that has formed to mature, as the membrane used is impermeable and nutrients are not able to pass through to the reparation area. It is the periosteum itself that has to encourage this process once the barrier has been removed. The results reveal on average a greater amount of bone tissue in the parameters evaluated. Palatal height was the only parameter evaluated that did not have a statistically significant result. In spite of this, the values of the second measurements of this parameter gave a final pos- 
cial del perióstio, el cual al ser seccionado en su base podría limitar parte de la irrigación de la zona desfavoreciendo el proceso de la osteogénesis. ${ }^{24-26}$ En este sitio en particular la exposición prematura de la membrana no la consideramos, por sí sola, como una causa de la pérdida de la altura ósea, dado los muy buenos resultados de otros sitios que presentaron de igual forma exposición, pero que a diferencia de este se ubicaron en el maxilar.

La exposición prematura de la membrana de los sitios 1,2 y 4 podría tener relación con más de un factor. Los pacientes de los sitios 1 y 4 eran individuos cuya actividad laboral les exigía comunicarse verbalmente (Educadora de Párvulos y Médico Veterinario respectivamente). Este hecho habría favorecido la tracción del colgajo cuyo perióstio fue seccionado parcialmente en su base. Por otro lado, el implante alojado en el sitio 1 fue inmediato, esto obligó a seccionar más profundamente el perióstio para dar mayor elasticidad al colgajo y cubrir el implante y la membrana en un amplio alvéolo de la región molar.

Tal vez el protocolo quirúrgico podría ser levemente modificado, esperando un tiempo prudente después de la extracción hasta contar con una suficiente cantidad de tejido blando que permita evitar la sección del perióstio y suturar con menor tensión.

Por otro lado, a pesar de que el implante alojado en el sitio 4 fue mediato, es decir, contaba con tejido blando suficiente como para lograr un buen cierre primario, la membrana se expuso prematuramente. Con todo, los resultados de las segundas mediciones de este sitio estudiado fueron notables. La exposición prematura de la membrana en este caso no trajo ninguna complicación ni pérdida ósea como ha ocurrido con el estudio de otras membranas cuya exposición prematura resulta en infección y pérdida de hueso. $22-23-25 \mathrm{El}$ uso del colutorio de clorhexidina en los pacientes que presentaron exposición prematura, sin duda, contribuyó a mantener un buen control de placa y a evitar cualquier complicación infecciosa que obligara a la remoción anticipada de la membrana.

El sitio $\mathrm{N}^{\circ} 3$, a pesar de alojar un implante inmediato no presentó exposición de la membrana y en la evaluación radiográfica pudo observarse la indemnidad de la cresta ósea alveolar a los 3 meses y medio, es decir, la membrana alúmina, sirvió también para mantener las dimensiones originales del reborde e incluso aumentarlas, obteniéndose una ganancia promedio de $\mathrm{mm}$ en todos los parámetros estudiados. Este hecho toma una gran importancia si consideramos la rehabilitación futura del lugar, ya que la membrana favorecería la regeneración ósea de la zona e impediría uno de los problemas mas triviales que acompaña a las extracciones dentales, esto es, la reabsorción ósea.

\section{Conclusiones}

La membrana de óxido de aluminio es capaz de mantener los tejidos extra esqueletales aislados del lugar de reparación ósea, evitando la migración de células epiteliales y del tejido conectivo, permitiendo incluso en los casos donde se expuso la membrana la reparación de las dehiscencias producidas al momento de instalación de los implantes, lo que produjo una ganancia en sentido vertical (excepto sitio $\mathrm{N}^{\circ} 1$ ) como horizontal del reborde, a pesar de no utilizar mate- itive result. That is to say, a gain in mm was obtained, but to a lesser extent than in the rest.

The difference in the results regarding palatal and vestibular height should not be surprising if we take into consideration that, in general, dehiscences arise in the vestibular area. On the other hand, numerous studies carried out previously's have attributed to the membranes used for GTR, a greater ability for alveolar ridge recovery in a horizontal sense than in a vertical sense, mainly due to the tendency of these to collapse, as a result of pressure from soft tissues.

The membrane used in this study showed no sign of collapse and in all cases the results were favorable. However, given the fact that a medium thickness membrane was used, which is not usually indicated for a considerable height increases, this gain was achieved and a large space underneath was avoided, particularly heightwise, on being adapted to the sites in the study. This could have been the motive for the later height measurements being clinically less significant.

Site $N^{\circ} 1$ that corresponded to the socket of tooth 19 , was the only site situated in the mandible and the only site to suffer height loss, vestibular as well as palatal. The type of irrigation in the mandible and the design of the flap (Newman) could explain in part these results. Vascular supply to the mandible depends principally on soft tissue supply, particularly from the periosteum, which on being sectioned from its base could limit part of the irrigation to the area, hampering the osteogenesis process. ${ }^{24-26}$ In this site in particular, we did not consider premature membrane exposure on its own, as a reason behind the loss in bone height, given the very good results in other sites, which similarly suffered exposures, but were situated in the maxilla unlike in this case.

Premature exposure of the membrane in Sites 1,2 and 4 could be related to more than one factor. The patients in Sites 1 and 4 were individuals with jobs that required them to communicate verbally (kindergarten teacher and Vet respectively). This could have favored the traction of the flap with the periosteum that was sectioned practically at its base. On the other hand, the implant situated in Site $N^{\circ} 1$ was immediate, and this made it necessary to section the periosteum more deeply in order to give the flap greater elasticity and to cover the implant and the membrane of a wide socket in the molar region.

Perhaps the surgical protocol could be slightly modified, and a prudent post-extraction time period could be observed, until a sufficient amount of soft tissue appeared that would enable us to avoid sectioning the periosteum and to suture with less tension.

On the other hand, in spite of the implant in Site 4 being immediate, that is, it had sufficient soft tissue to enable good primary closure, the membrane became exposed prematurely. In spite of this, the results of the second measurements in this site were noteworthy. Premature exposure of the membrane in this case did not lead to any complication or bone loss as occurred in the study of other membranes with premature exposure that led to infection and bone loss. ${ }^{22-}$ 
rial de injerto bajo ella, quedando el espacio creado, ocupado por el coágulo, lo cual hipotéticamente favorecería la concentración de los factores de crecimiento y por lo tanto la osteogénesis.

\section{Sugerencias}

- Utilizar la membrana de óxido de aluminio en un mayor número de pacientes

- Realizar estudios histológicos del tejido formado inmediatamente bajo ella

- Hacer estudios microbiológicos de adherencia bacteriana a la membrana

- Finalmente podemos sugerir esperar el cierre mucoso antes de alojar los implantes y las membranas una vez realizada la exodoncia. De esta manera, podría evitarse la tensión del cierre primario y la sección del peri'Ostio.

\section{Agradecimientos}

A la empresa Demac por la donación de la membrana Allumi$n a^{\circledR}$.

Al Doctor Benjamín Martínez, expatólogo de la Universidad de Chile y actual docente de Bioestadística de la Universidad Mayor por la asesoría en los análisis estadísticos.

\section{Bibliografía}

1. Christop y cols. Single stage surgery combining transmucosal implant placement with guided bone regeneration and bioresorbable materials. Clin Oral Impl Res 2001;12:9-18.

2. Otti $\mathrm{P}, \mathrm{y}$ cols. The Procera AllCeram Sistem. Int / Periodontics Restorative dent 2000; 20:151-61.

3. Malmquist J, y cols. Successful implant restoration with the use of barrier membranes. J Oral Maxillofac Surg 1999;57:1114-6.

4. Dupoirieux $L, y$ cols. Comparative study of three different membranes for guided bone regeneration of rat cranial defects. Int J Maxillofac Surg 2001;30:5862.

5. Dörfer $\mathrm{C}, \mathrm{y}$ cols. Regenerative periodontal surgery in interproximal intrabony defects with biodegradable barriers. / Clin Periodontal 2000;27:162-8.

6. Zitzmann $\mathrm{N}, \mathrm{y}$ cols. Long-term results of implants treated with guided bone regeneration: A 5-year prospective study. Int J Oral Maxillofac Impl 2001;16:35566.

7. Karapataki $S$, y cols. Healing following GTR treatment of intrabony defects distal to mandibular 2nd molars using resorbable and non-resorbable barriers. J Clin Periodontal 2000;27:333-40.

8. Cruz M, y cols. Utilicao da alumina como membrana na Regeneracao Guiada dos Tecidos. Odontologico Moderno Sao Paulo 1993;20:6-13.

9. Yasonuri $S$, y cols. Aumento del reborde alveolar con redes de titanio y hueso autógeno. Oral Surg Oral Med Oral Pathol 2000;89:268-70.

10. Nociti F, y cols. Absorbable versus non-absorbable membranes and bone grafts in the treatment of ligature-induced peri-implantitis defects in dogs: A histometric investigation. Int J Oral Maxillofac Impl 2001;16:646-52.
23-25 The use of chlorhexidine rinses in patients with premature exposure without doubt contributed to maintaining good plaque control and any infectious complications that would have hastened the removal of the membrane were avoided.

Site $\mathrm{N}^{0} 3$ did not suffer membrane exposure despite having an immediate implant, and in the radiographic evaluation an intact alveolar bone crest could be observed at three and $a$ half months. That is to say, the aluminum membrane also served to maintain the original dimensions of the border, and even to increase them, and an average $\mathrm{mm}$ gain was obtained in all the parameters studied. This fact is of great importance if we consider the future rehabilitation of the site, as the membrane encourages bone regeneration in the area and it halts one of the most trivial problems of dental extractions, which is bone resorption.

\section{Conclusions}

Aluminum oxide membrane is capable of maintaining extra-skeletal tissue isolated from the bone repair site, and it avoids the migration of epithelial cells and of connective tissue. Even in the cases where the membrane became exposed, dehiscences were repaired on installing the implants, which led to an increase in the vertical (except in site $N^{0} 1$ ) as well as horizontal dimension of the ridge, despite not using any graft material underneath, and the space created was filled by the blood clot, which hypothetically favors the concentration of growth factors and therefore, of osteogenesis.

\section{Suggestions}

- Aluminum oxide membranes should be used in a larger number of patients.

- Histological studies should be carried out of the tissue formed directly underneath the membrane.

- Microbiological studies should be carried out on the adherence of bacteria to the membrane

- Finally we would like to suggest waiting for mucosal closure before placing the implants and membranes once the extraction has been carried out. In this way, primary closure tension can be avoided and the sectioning the periosteum.

\section{Acknowledgments}

To the company Demac for donating Allumina® membrane.

To Doctor Benjamin Martinez, ex-pathologist of the "Univesidad de Chile" and staff member of the "Bioestadística de la Universidad Mayor" for his assessment in the statistical analysis. 
11. Barry K, y cols. Extraction site reconstruction for alveolar ridge preservation. Part 1: Rationale and material selection. Journal of Oral Implantology 2001;27:187-93.

12. Barry K,y cols. Extraction site reconstruction for alveolar ridge preservation. Part 2: Membrane-Assisted surgical technique. Journal of Oral Implantology 2001;27:194-7.

13. Bunyaratavej P, y cols. Collagen Membranes: A Review. J Periodontol 2001;72:215-29.

14. Celleti R, y cols. Guided tissue regeneration around dental implants in immediate extraction sockets: Comparison of e-PTFE and a new titanium membrane. Int Periodont Rest Dent 1994;14:243-53.

15. Mohamed A, y cols. Immediate implants in fresh posterior extraccion sockets: Report of two cases. J Oral Implantol 2001; 2:123-6.

16. Marlin E, Gher et. al. Combined dental implant and guided tissue regeneration therapy in humans. Int / Periodont Rest Dent 1994;14:333-47.

17. Nociti F, y cols. Absorbable versus nonabsorbable membranes and bone grafts in the treatment of ligature-induced periimplantitis defects in dogs. Clin Oral Imp/ Rest 2001;12:115-20.

18. Massimo $\mathrm{M}$, y cols. Vertical ridge augmentation using a membrane technique associated with osseointegrated implants. Int J Periodont Rest Dent 1994;14:497-511.

19. Diès $F, y$ cols. Bone regeneration in extraction sites after inmediate placement of an e-PTFE membrane with or without a biomaterial. Clin Oral Impl Res 1996; 7:277-85.

20. Von Arx, y cols. Lateral ridge augmentation using difeerent bone fillers and barriers membrane application. Clin Oral Impl Res 2001;12:2609.

21. Buser $D, y$ cols. Regeneration and enlargement of jaw bone using guided tissue regeneration. Clin Oral Impl Rest 1990;1:22-32.

22. Gher $\mathrm{M}, \mathrm{y}$ cols. Bone grafting and guided bone regeneration for immediate dental implants in humans. J Periodontol 1994;65:881-91.
23. Wang $\mathrm{H}$; y cols. Adherence of oral microorgenisms to guided tissue membranes: In vitro study. J Periodontol 1994;65:211-8.

24. Testut L, Jacob O. Tratado de Anatomía Topográfica con aplicaciones medicoquirúrgicas. 1964:207.

25. Isa M y col. Uso de la membrana Allumina ${ }^{\circledR}$ en la preservación del reborde alveolar postextracción. Magazine Internacional College of Dentists Section Four 2001;8:61-8.

26. Walter JB, Hamilton MC, Israel MS. Principles of pathology for dental students. (4a.ed). Edinburgh: Churchill Livingstone, 1981;p.p.570.

27. Guitián $\mathrm{P}, \mathrm{y}$ cols. Preparación de cavidades por microabrasión. Facultad de Medicina y Odontología de la universidad Santiago de Compostela. http://www.infomed.es/mode/mode97/mesa3.html.

28. Peterson A, y cols. Avaliacao cínica da técnica de regeneracao tecidual guiada utilizando uma barreira de óxido de alumínio no tratamento de lesoes de furca classe II em humanos: relato de 12 casos. Projecto fundo de incentivo a pesquisa (FIP), $n^{\circ}$ 94/022 Pontificia Universidad de Católica de Minas Gerais.

29. Wilson T, y cols. Implants placed in immediate extraccion sites: a report of histologic and histometric analysis of human biopsies. Int J Oral Maxillofac Impl 1998;13:333-41.

30. Steven G, Lewis. Sisitema de implantes Branemark. Editorial Espax S.A. 1991; p.p. 1-10.

31. Nyman, y cols. New attachment following surgical treatment of human periodontal disease. J Clin Periodontol 1982;9:290-6.

32. Takashi T, y cols. Migration of osteoblastic cells on various guided bone regeneration membranes. Clin Oral Impl Res 2001;12:332-8.

33. Rocuzzo M, y cols. Comparative study of a bioresorbable and a nonbioresorbable membrane in treatment of human bucal gingival recessions. J Periodontol 1996;67:7-14.

34. Piattelli A, y cols. Histological evaluation of bone reaction to aluminium oxide dental implants in man. Biomaterials 1996;17:711-4. 